\title{
Immunogenicity of Recombinant DNA Vaccine Encoding Non-Structural Protein-1 Dengue Virus Serotype-2 in Balb/c Mice
}

\author{
FITHRIYAH SJATHA ${ }^{1}$, ELITHA SUNDARI PULUNGAN ${ }^{2 *}$, AND TJAHJANI MIRAWATI \\ SUDIRO ${ }^{1}$
}

\author{
${ }^{I}$ Department of Microbiology, Medical Faculty, Universitas Indonesia, Indonesia; \\ ${ }^{2}$ Master Programme of Biomedical Science, Faculty of Medicine, Universitas Indonesia, Indonesia.
}

\begin{abstract}
Dengue Hemorrhagic Fever (DHF) is an infectious disease caused by the dengue virus (DENV) which spread widely in tropical and subtropical regions of the world. DENV is a single-positive strand RNA virus with a genome size of $\pm 11 \mathrm{~kb}$ which encodes three structural proteins, seven non-structural proteins, and two untranslated regions (UTR). The non-structural protein-1 (NS1) of DENV is known to have important role in dengue pathogenesis also promising to be developed as dengue vaccine. Lately, novel vaccine approach by DNA immunization have given new perspective for a safe, stable, and immunogenic vaccine platform. Previously, we had successfully constructed DNA vaccine encoding NS1 protein of DENV2 (pUNS1) which expressed recombinant NS1 protein in mammalian cells line. Thus, in this current study the ability of pUNS1 to induce humoral immune response will be further analyzed by in mice immunization. Sixteen BALB/c mice aged of 4 weeks were immunized 3 times with $100 \mu \mathrm{g}$ of pUNS1 or pUMVC4a on 2 weeks interval. Blood sampling was carried out just before immunization and termination was done 2 weeks after last immunization. Antibodies titer from individual mice sera against DENV-2 were measured with in-house ELISA. Anti-dengue NS1 IgG titer from mice group immunized with recombinant pUNS1 Showed ELISA absorbances five times higher than pUMVC4a group. This result suggested the ability of pUNS1 to induce humoral immune response against NS1 DENV-2 invivo. Recombinant pUNS1 can induce humoral immune response in mice.
\end{abstract}

Key words: dengue virus serotype-2 (DENV-2), humoral immune response, NS1, recombinant DNA

Demam Berdarah Dengue (DBD) adalah infeksi yang disebabkan oleh virus dengue (DENV) yang tersebar luas di wilayah tropis dan subtropis di dunia. DENV merupakan virus RNA rantai tunggal dengan ukuran genom \pm $11 \mathrm{~kb}$ yang mengkode tiga protein struktural, tujuh protein non-struktural, dan dua daerah yang tidak ditranslasikan (UTR). Protein non-struktural (NS1) DENV diketahui memiliki peran yang sangat penting dalam patogenesis infeksi DENV dan sebagai pengembangan vaksin dengue yang menjanjikan. Saat ini, pengembangan vaksin baru dengan DNA yang diimunisasikan memberikan perspektif baru karena aman, stabil, dan imunogenik. Pada penelitian sebelumnya, kami telah berhasil mengonstruksi vaksin rekombinan DNA yang mengkode protein NSI dari DENV-2 (pUNS1) dan diekspresikan pada sel mamalia. Oleh karena itu, pada penelitian ini dilakukan analisis lebih lanjut untuk melihat kemampuan pUNS1 dalam menginduksi respon imun humoral dengan imunisasi pada mencit. Sebanyak 16 mencit BALB/c yang berumur 4 minggu diimunisasi sebanyak 3 kali dengan $100 \mu \mathrm{g}$ pUNS1 atau pUMVC4a dalam interval waktu 2 minggu. Pengambilan sampel darah mencit dilakukan sebelum imunisasi dan dilakukan terminasi 2 minggu setelah imunisasi terakhir. Titer antibodi dari serum masingmasing mencit diukur dengan ELISA in-house. Titer IgG anti protein NS1 dari DENV2 dari kelompok mencit yang diimunisasi dengan rekombinan pUNS1 menunjukkan nilai absorbansi yang tinggi, 5 kali lebih tinggi dari kelompok pUMVC4a. Hal ini membuktikan kemampuan pUNS1 dalam menginduksi respon imun humoral terhadap NS1 DENV-2 secara in-vivo. Rekombinan pUNS1 dapat menginduksi respon imun humoral mencit.

Kata kunci: dengue virus serotipe 2 (DENV-2), DNA rekombinan, NS1, respon imun humoral

Dengue Hemorrhagic Fever (DHF) is an infectious disease caused by the dengue virus (DENV). Dengue virus infection is a global health problem that occurs in tropical and subtropical regions of the world. Based on data from the WHO (World Health Organization) this disease has progressed to cause nearly 390 million people to be infected each year, including more than 960,000 cases of severe dengue (WHO 2016).

*Corresponding author: Phone: +62-82218723138; E-mail: elithasundaripulungan@gmail.com
DENV belongs to the family Flaviviridae, of the genus Flavivirus. Dengue virion morphology is spherical with a diameter of $\pm 50 \mathrm{~nm}$. The outer part of the virion is covered by a sheath in the form of a membrane lipid with a sheath thickness of $\pm 10 \mathrm{~nm}$ with Nucleocapsid inside about $\pm 30 \mathrm{~nm}$ in diameter. DENV genetic material in the form of positive RNA single strand with a length of $\pm 11 \mathrm{~kb}$. The genome of this virus encodes a large polyprotein which is divided into three structural proteins (capsid (C); membrane precusor (prM); and envelope (E)), seven non-structural (NS) 
proteins (NS1, NS2a, NS2b, NS3, NS4a, NS4b, and NS5), and two regions that are not translated or called the Untranslated Region (UTR) (Putnak et al. 2003; Lin et al. 2012). Base on genetically, dengue virus has four different serotypes are DENV-1, DENV-2, DENV-3, and DENV-4. Each DENV serotype has a protein E amino acid sequence homology of about 70\% (Lin et al. 2012).

NS1 protein is a glycoprotein weighing $42-50 \mathrm{kDa}$ from 353-354 amino acids encoded by 1056bp of genes (Clyde et al. 2006). This protein with other viral proteins can fulfill a structural role, helping to anchor the replication complex to the membrane and induce the formation of membrane components that facilitate viral RNA replication, assembly and release of viruses, immune avoidance, and various aspects of pathogenesis (Glasner et al. 2018). There are two form of NS1 which expressed by infected host cell, on cell surface (mNS1 protein) and secreted into the extracellular environment (sNS1 protein). In the process of infection, $\mathrm{mNS1}$ will be presented by Major Histocompatibility Complex (MHC) molecules and can induce the immune response. Meanwhile, sNS1 can directly bind to various components of the complement pathway which either trigger or inhibit the activity of complement also can be used as a marker because the presence of high levels of NS1 have shown an association between the severity of dengue virus infection (Henrique et al. 2014; Watterson etal. 2016).

The NS1 protein is able to activate endothelial cells directly and decrease the integrity of the endothelial cell barrier through dependent TLR4 pathway (Henrique et al. 2014). When DENV infects, the body can activate the cellular immune system and the humoral immune system in response to fight. As a result of the humoral immune system, dengue virus infection can lead to the formation of short-term protective antibodies in the form of immunoglobulin $\mathrm{M}$ (IgM) and long-term protective antibodies in the form of immunoglobulin $\mathrm{G}$ ( $\mathrm{IgG}$ ) against the virus (Shu P.Y. et al. 2000).

In contrast to viral structural proteins that induce neutralizing antibodies, NS1 protein can induce antiNS1 antibodies. So, it's not inducing ADE (antibody dependent enhancement) activity which raised from $\mathrm{M}$ or E protein based vaccine (Hertz, et al. 2017). Recombinant DNA plasmid can be delivered to the host in several ways and methods so that it may mimic some aspects of the natural infection of the host cells. Compared to recombinant protein and recombinant virus vaccines, DNA vaccines are relatively inexpensive, have low production costs, easy to manufacture and use, and safe because it is not pathogenic but still immunogenicity. This is based on the possibility of the DNA vaccine can induce $\mathrm{CD}^{+}$and $\mathrm{CD}^{+} \mathrm{T}$ cells so that stimulate the immune response through the MHC-I and MHC-II pathways (Leitner et al. 2007). In addition, a recombinant DNA plasmid is another potential strategy for the development of an NS1-based vaccine (Liu, Y.et al. 2016).

Several DENV vaccine approach based on NS1 protein are widely developed. In our previous study, we successfully constructed and proven that our recombinant pUNS1 (recombinant puMVC4.a encoding NS1 protein of DENV-2) able to express its protein in mammalian cell line (Sjatha et al. 2019). Furthermore, this current study will be analyzed the ability of our recombinant pUNS1 to induce humoral immune response in mice as initial evaluation of pUNS1 antigenicity as DNA vaccine.

\section{MATERIALS AND METHODS}

Ethics Statement and Mice. All protocols within this experiment have been ethically approved by Health Research Ethics Committee Faculty of Medicine Universitas Indonesia-RSCM number: KET1350/UN2.F1/ETIK/PPM.00.02/2019. Animal experiments were carried out using $16 \mathrm{Balb} / \mathrm{c}$ mice in total, which were divided into two groups: (1) eight mice were immunized with pUMVC4.a control plasmid and (2) eight mice were immunized with pUNS1. Experiment in mice was carried out by experienced and certified animal welfare staff and under the supervision of attending veterinary. The animal experiment was carried out in the animal care facility of the Department of Microbiology, Faculty of Medicine Universitas Indonesia with a closed cage system and ad libitum feed-drink.

Viruses. The virus used as antigen for in-house ELISA was dengue virus serotype-2 (DENV-2) NCG (New Guinea C) strain harvested at 6 d.p.i titer of $5.02 \mathrm{x}$ $10^{7} \mathrm{FFU} / \mathrm{ml}$.

Propagation of Escherichia coli Harboring Plasmid. DH5 $\alpha$ competent cells Escherichia coli that has carried the recombinant pUNS1 and pUMV4.a plasmid were propagated in liquid Luria Bertani (LB) medium. To produce starter cultures, bacterial clones containing recombinant plasmids were streaked on solid LB medium containing $50 \mu \mathrm{g} / \mu \mathrm{l}$ kanamycin and incubated at $37^{\circ} \mathrm{C}$ for 24 hours, then one loop of bacterial colony was inoculated in $5 \mathrm{ml}$ liquid LB 
medium containing $50 \mu \mathrm{g} / \mu \mathrm{l}$ kanamycin and incubated at $37^{\circ} \mathrm{C}, 200 \mathrm{rpm}$. After $18-20$ hours, $2 \mathrm{ml}$ of liquid culture was moved in to $200 \mathrm{ml}$ of fresh liquid LB medium containing $50 \mu \mathrm{g} / \mu \mathrm{l}$ kanamycin. Then, reincubated at $37^{\circ} \mathrm{C}, 200 \mathrm{rpm}$ for $18-20$ hours. When the cell density reach OD equal to $3-4 \times 10^{9}$ cells $/ \mathrm{ml}$, the cells were harvested. The bacterial culture was centrifuged at $4000 \mathrm{rpm}$ for 10 minutes at $17^{\circ} \mathrm{C}$ to get bacterial cell pellet.

Plasmid Isolation. Plasmid isolation from bacterial pellet was carried out following the HiSpeed ${ }^{\circledR}$ Plasmid Midi Kit (Qiagen, catalog no: 12643) protocol. Pure DNA plasmids were confirmed by gel electrophoresis and stored at $-30^{\circ} \mathrm{C}$. Plasmid concentrations were measured using spectophotometry method.

Confirmation of pUNS1 by PCR. PCR reaction was performed using (Invitrogen, catalog no: 10342053). Composition of PCR reaction as much: $2.5 \mu \mathrm{l}$ of PCR master mix; $15.25 \mu \mathrm{l}$ of DW; $2.5 \mu \mathrm{l}$ of dNTP $2 \mathrm{mM} ; 1 \mu \mathrm{l}$ of $\mathrm{MgCl}_{2} 50 \mathrm{mM} ; 0.8 \mu \mathrm{l}$ of Reverse primer $350 \mathrm{XbaI}(10 \mathrm{mM}) ; 0.8 \mu \mathrm{l}$ of Primary Forward 2329 sBam $(10 \mathrm{mM}) ; 0.15 \mu \mathrm{l}$ of Taq DNA polymerase enzyme (Invitrogen, catalog no: 10342-053).; and $2 \mu 1$ of plasmid template. The PCR cycles used were: $95^{\circ} \mathrm{C}$ for 5 minutes; followed by 40 cycles of $95^{\circ} \mathrm{C}$ for 30 seconds; $55^{\circ} \mathrm{C}$ for 30 seconds; $72^{\circ} \mathrm{C}$ for 90 seconds; and ended was $72^{\circ} \mathrm{C}$ for 5 minutes. Marker used was $\lambda$ DNA HindIII (Tiangen, catalog no: Md202).

Mice Immunization. Sixteen Balb/c mice were immunized with $100 \mu \mathrm{g}$ pUNS1 and pUMVC4.a plasmid using NFI (needle free injector, ShimaJet, Japan) apparatus. Immunizations were held within 3 doses in 2 weeks interval and retro-orbital blood were taken prior to immunization under the sedation of ketamine-xylasine treatment. Two weeks after third immunization, mice were terminated through cervical dislocation and blood were drawn by cardiac puncture. Mice blood were then centrifuged at $3000 \mathrm{rpm}$ for 5 minutes and collected sera were stored at $-70^{\circ} \mathrm{C}$ until further examination.

Anti-NS1 IgG of DENV2 analysis with in-house ELISA. Termination individual mice sera from both groups were tested for IgG recognizing NS1 of DENV2 with in-house ELISA. Briefly, flat bottom 96well ELISA plate (NUNC, catalog no: 442404) were coated with $10^{4} \mathrm{FFU} / \mathrm{ml}$ DENV2 in bicarbonate buffer $\mathrm{pH} 9.6$ overnight at $4^{\circ} \mathrm{C}$. Plate were washed third with PBS containing $0.05 \%$ tween 20 . Negative control antigen was PBS $1 \mathrm{x}$, negative control sera were preimmunized sera, and positive control were mice sera immunized with DENV-2. ELISA plate wells were coated with DENV-2 antigen with the same titer in each well. The coating process is carried out overnight at $4^{\circ} \mathrm{C}$. The plate washed 3 times with PBS containing $0.05 \%$ Tween 20 , followed by $5 \%$ skim milk blocking at $37^{\circ} \mathrm{C}$ for 1 -hour incubation. Then, ELISA plate was washed followed by addition of $100 \mu$ of diluted (1:200) serum samples and incubation at $37^{\circ} \mathrm{C}$ for 1 hour. After incubation, plate was washed and diluted horse anti mouse-IgG HRP labeled (1:5000; Vector Laboratories, Catalog No: PI-2000) were added followed by incubation at $37^{\circ} \mathrm{C}$ for 1 hour. After incubation, plate was washed and $80 \mu \mathrm{l}$ of TMB substrate (1-Step, Catalog No: 34028) was added followed by incubation in dark with gentle agitation for 20 minutes at RT. Finally, $30 \mu \mathrm{l}$ of stop solution was added and absorbances were measured at $450 \mathrm{~nm}$.

Statistical Analysis. Numerical data obtained from ELISA were analyzed using SPSS program, tested for its normality by Shapiro Wilk test, followed by t-test. For significances at $p$ value $<0.05$ and confidence level $95 \%$.

\section{RESULTS}

\section{Recombinant Plasmid pUNS1 Confirmation.} PCR was performed to confirm the NS1 gene in pUNS1. The pUMVC4.a plasmid was used as negative control. As seen in Figure 1, the presence of NS1 could be detected in the recombinant plasmid pUNS1. This is indicated by the presence of a band in the pUNS1 lane. Recombinant pUNS1 had NS1 gene insertion of 1056 bp size based on colony PCR analysis.

Evaluation of anti DENV2 IgG Titer. Pre and post-immunization serum of individual mice sera from both pUNS1 and pUMVC4.a groups were used to measure IgG antibody titers induced by recombinant pUNS1 against DENV2. As seen in Figure 2, preimmunization serum from both pUNS1 (Mean \pm SD: $0.137 \pm 0.008$ ) and pUMVC4.a (Mean \pm SD: $0.138 \pm$ 0.009 ) group showed similar absorbances value. However, post-immunization serum mice's with pUNS1 (Mean \pm SD: $1.508 \pm 0.039$ ) had anti DENV2 IgG value higher than mice immunized with pUMVC4a (Mean \pm SD: $0.294 \pm 0.034$ ). This difference is said to be significant with a confidence level of $95 \%(\mathrm{p}<0.05)$. These results indicate that the pUNS1 recombinant was able to induce humoral immune response in mice, with 5 times fold higher than pUMVC4. a control group in recognizing DENV-2. 


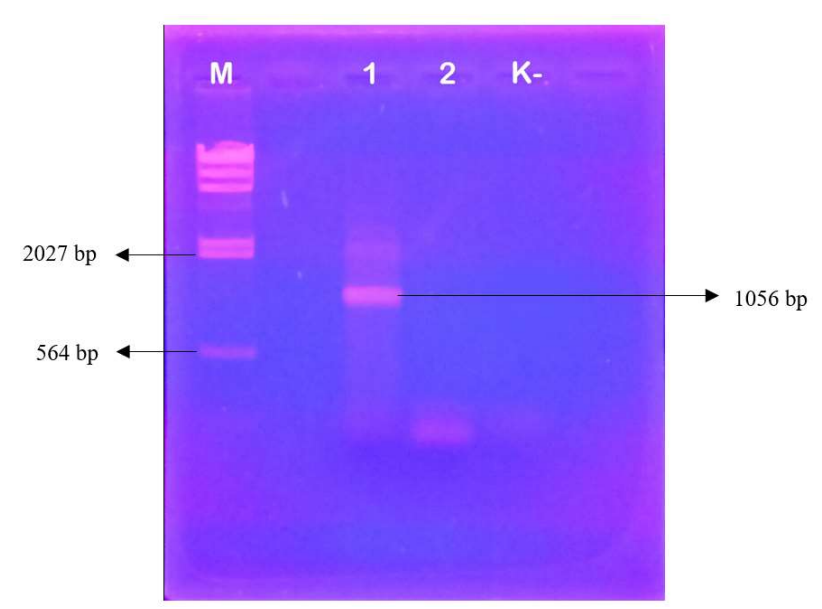

Fig 1 NS1 insert confirmation by PCR. M: Marker, 1: recombinant plasmid pUNS1, 2: plasmid pUMVC4.a, K-: negative control PCR.

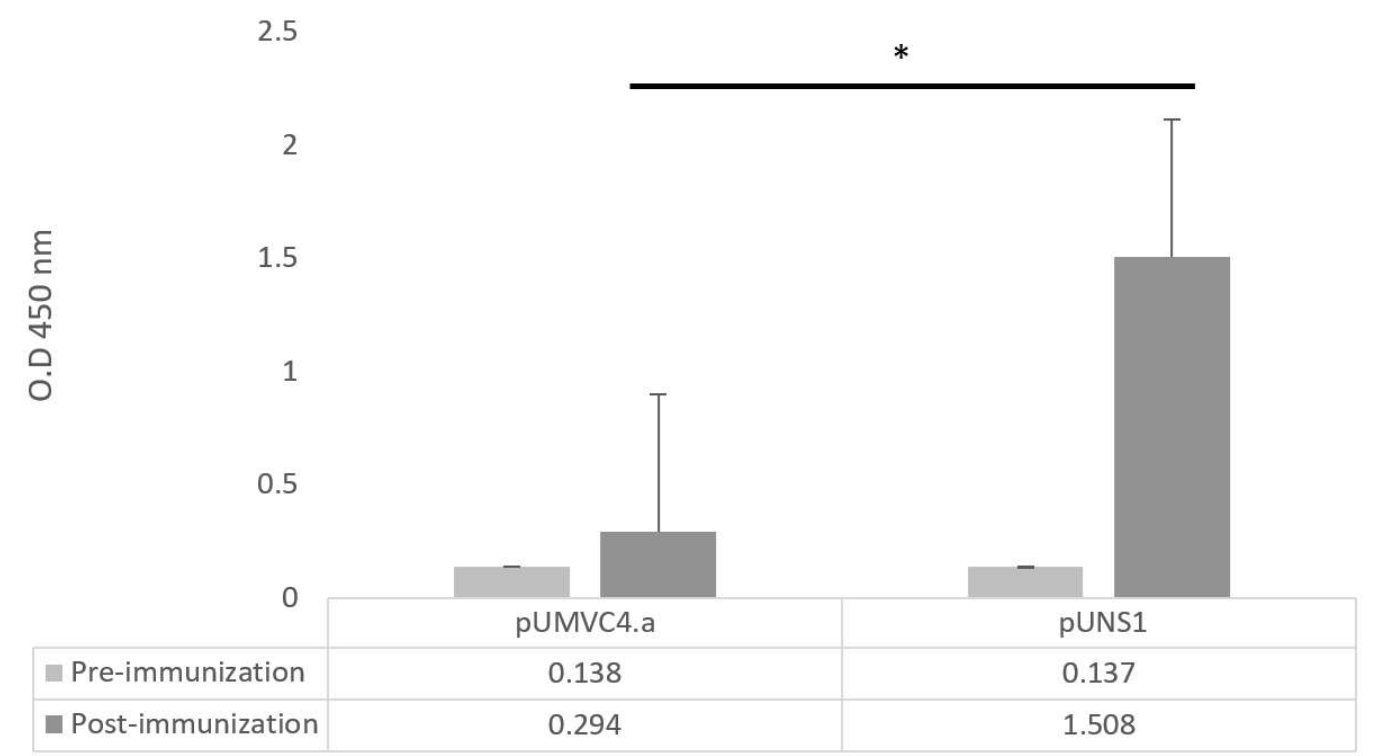

Fig 2 Antibody titer from mice group immunized with pUNS1 and pUMVC4a using in-house ELISA $(* p<0.05)$.

\section{DISCUSSION}

Secreted and membrane-associated of DENV NS1 are highly immunogenic because it can induce immune system correspond to the production of antibody against NS1 which also detected in infected patients (Chuang, Y-C, et al. 2013). It has been found that DENV NS1 protein with high levels is associated with severity of infection and levels $>600 \mathrm{ng} / \mathrm{ml}$ in the first 72 hours of disease occurrence associated with the development of DHF (Libraty et al. 2000). Thus, NS1 is also developed as DENV vaccine approach since its advantages for not inducing ADE (antibody dependent enhancement) activity which raised from $\mathrm{M}$ or $\mathrm{E}$ protein based vaccine (Hertz, et al. 2017).

Although NS1 can induce non-neutralizing antibodies, there have been reported problems. AntiNS1 antibodies can cross-react with coagulationrelated cells or molecules, such as human plasminogen, thrombin, platelets, and endothelial cells (Chuang, YC, et al. 2013). These anti-NS1 autoantibodies can cause thrombocytopenia and apoptosis mediated by nitric oxidation in endothelial cells in vitro (Lin, C-F, et al. 2002). Because of the homology of the sequences between the NS1 DENV protein and proteins in platelets and endothelial cells, it is possible that these autoantibodies are induced by NS1 through molecular mimicry (Lin, Y-S, et al. 2011). Although in vitro has shown the potential of cross-reaction between antiNS1 antibodies and endothelial cells and platelets, this finding has not been supported or proven in vivo (Sun, D-S, etal. 2007). 
An alternative vaccine delivery strategy can be performed to get better vaccine outcome. In this study, we use NFI (needle free injector) as apparatus to introduce DNA vaccine in Balb/c mice which proven to be more effective in delivering DNA in to target cell compare to syringe-based immunization. In the present needle-free immunization strategy, the vaccine plasmid could directly enter a relatively large number of muscle cells in the thigh of host animals (Imoto, J-I, et al. 2005).

After immunization, DNA vaccine can be uptake by the muscle cells and neighboring antigen presenting cells. The injected DNA vaccine will express the recombinant protein as endogenous antigen and presented by MHC class I. On the other hand, antigen can be released through extra cellular and further taken up by circulated APCs which lately presenting recombinant protein by MHC class II. The antigenexpressing APCs then migrate to lymph nodes where they activate the $\mathrm{T}$ and $\mathrm{B}$ lymphocytes to induce cellular and humoral immune responses (Leitner $e t$ al. 2007).

Although antigen presentation by both MHC class I and II, DNA vaccine have other advantages. DNA vaccine are safer, more stable for storage and shipping, easy to handle, induce cellular immune responses, licensed veterinary vaccine, relatively generic construction and production, and potent prime in animal studies (Khan 2013; Liu 2010). One of disadvantages of DNA vaccine is inducing antibody production against DNA (Khan 2013). In our result, IgG response of control pUMVC4.a group is also detected in low level of absorbances. This result may occur because of factors influencing immune responses against the vector such as route of administration, dose of vector, host-related factors, and promoters (Bessis et al. 2004). Antivector immunity was found in mice injected with the plasmid intraperitoneally, intravenously, or subcutaneosly. Besides producing antibodies against the inserted gene, specific cytotoxic $T$ cells were also found in the plasmids used. However, in mice injected with plasmids intramuscularly, the humoral immune response was obtained but with a lower cytotoxic $\mathrm{T}$ cell response (Brockstedt et al., 1999). A study of plasmidinduced endothelial cells demonstrated the productivity of the cytokines TNF- $\alpha$, IL-1 $\beta$, and IL-4 which increased promoter activity (Ritter et al. 2000). Sjatha et al. 2019, showed that levels of the cytokine TNF- $\alpha$ in CHO-K1 mammalian cell line which transfected by pcNS1 was higher compared control.
Also in our result showed IgG recognizing DENV2 obtaining from pUNS1 group has shown 5 times higher absorbances level compare to control pUMVC4.a group, indicating high production of recombinant NS1 expression and its immunogenicity in inducing humoral IgG response. Kim et al. 2010, showed DNA vaccines may have a relatively poor immunogenicity. This can be overcome by increasing the potential mechanisms of DNA vaccine such as plasmid alterations, increasing the stability of the DNA by formulations and encapsulation, delivery, and augmentation of immunity (Liu 2010).

To evaluate our recombinant pUNS1 as DNA vaccine candidate, induced antibody may further analyzed for its ability to overcome DENV infection in-vitro or in-vivo. And also to evaluate the possibility of cross-reaction with other DENV serotype or other Flavivirus, cross-recognizing of antibody against NS1 protein to endothelial cell which lead to plasma leakage and also its ability to trigger complement cascade as vaccine safety concern.

In conclusion, we successfully prove the ability of our pUNS1 to induce humoral immune response in mice. Further analysis for its antibody protection against DENV can be performed as one parameter in vaccine development.

\section{ACKNOWLEDGEMENTS}

This research was funded by Hibah Penelitian Dasar Unggulan Perguruan Tinggi by the Ministry of Research and Higher Education, Republic of Indonesia 2019/2020.

\section{REFERENCES}

Bessis N, GraciaCozar FJ, and Boissier MC. 2004. Immune responses to gene therapy vectors: influence on vector function and effector mechanisms. Gene Threapy. 11: 10-14. doi: 10.1038/sj.gt.3302364.

Brockstedt DG, Podsakoff GM, Fong L, Kurtzman G, Ruchholtz WM, and Engleman EG. 1999. Induction of immunity to antigens expressed by recombinant adenoassociated virus depends on the route of administration. Clin Immunol. 92: 67-75. doi:10.1006/clim.1999.4724.

Chen HR, Chuang YC, Lin YS, Liu HS, Liu CC, Perng GC, and Yeh TM. 2016. Dengue virus nonstructural protein 1 induces vascular leakage through macrophage migration inhibitory factor and autophagy. PLoS Neglected Tropical Diseases. 10(7):e0004828. doi:10.1371/journal.pntd.0004828. 
Chuang YC, Lin J, Lin YS, Wang S, and Yeh TM. 2016. Dengue virus nonstructural protein 1-induced antibodies cross-react with human plasminogen and enhance its activation. The Journal of Immunology. 196 (3):1218-1226. doi:10.4049/jimmunol.1500057.

Chuang YC, Wang SY, Lin YS, Chen HR, and Yeh TM. 2013. Re-evaluation of the pathogenis roles of nonstructural protein 1 and its antibodies during dengue virus infection. Journal of Biomedical Science. 20 (1):42-48. doi:10.1186/1423-0127-20-42.

Clyde K, Kyle J, and Harris E. 2006. Recent advances in deciphering viral and host determinants of dengue virus replication and pathogenesis. Journal of Virology. 80(23):11418-11431. doi:10.1128/JVI.01257-06.

Glasner D, Puerta HG, Beatty P, and Harris E. 2018. The good, the bad, and the shocking: the multiple roles of dengue virus nonstructural protein 1 in protection and pathogenesis. Annual Review of Virology. 5(1):227253. doi:10.1146/annurev-virology-101416-041848.

Henrique J, Prince R, Beatriz S, Carlos L, and Ferreira DS. 2014. The dengue virus non-structural 1 protein : risks and benefits. Virus Research. 181:53-60. doi:10.1016/j.virusres.2014.01.001.

Hertz T, Beatty PR, Macmillen Z, Killingbeck SS, Wang C, and Harris E. 2017. Antibody epitopes identified in critical regions of dengue virus nonstructural 1 protein in mouse vaccination and natural human infections. $J$ I m muno 1. 198(10):4025-4035. do i : 10.4049/jimmunol.1700029.

Imoto JL and Konishi E. 2005. Needle-free jet injection of a mixture of Japanese encephalitis DNA and protein vaccines: a strategy to effectively enhance immunogenicity of the DNA vaccine in a murine model. Viral Immunol. 18(1):205-212. doi:10.1089/vim.2005.18.205.

Khan HK. 2013. DNA vaccines: roles against diseases. GERMS. 3(1):26-35. doi:10.11599/germs.2013.1034.

Leitner WW, Ying H, and Restifo NP. 2007. DNA and RNAbased vaccines: principles, progress and prospects. Vaccine. 18(9-10):765-777. doi:10.1016/s0264410x(99)00271-6.

Libraty DH, Young PR, Pickering D, Endy TP, Kalayanarooj S, Green S, Vaughn DW, Nisalak A, Ennis FA, and Rothman AL. 2002. High circulating levels of the dengue virus nonstructural protein NS1 early in dengue illness correlate with the development of dengue hemorrhagic fever. The Journal of Infectious Diseases. 186(6):1165-1168. doi:10.1086/343813.

Lin CF, Lei HY, Shiau AL, Liu HS, Yeh TM, Chen SH, Liu CC, Chiu SC, and Lin YS. 2002. Endothelial cell apoptosis induced by antibodies against dengue virus nonstructural protein 1 via production of nitric oxide. $\mathrm{J}$ I m m u o l. $169: 657-664$. $\mathrm{d}$ o i : 10.4049/jimmunol.169.2.657.
Lin HE, Tsai WY, Liu IJ, Li PC, Liao MY, Tsai JJ, Wu YC, Lai C, Lu CH, Huang JH, Chang GJ, Wu HC, and Wang WK. 2012. Analysis of epitopes on dengue virus envelope protein recognized by monoclonal antibodies and polyclonal human sera by a high throughput assay. PLoS Neglected Tropical Diseases. 6(1):e1447. doi:10.1371/journal.pntd.0001447.

Liu MA. 2010. Immunologic basic of vaccine vectors. Imunity. 33: 504-515. doi: 10.1016/j.immuni. 2010.10.004.

Liu Y, Liu J, and Cheng G. 2016. Vaccines and immunization strategies for dengue prevention. Emerging Microbes Infections. 5(7): e77. doi:10.1038/emi.2016.74.

Lin YS, Yeh TM, Lin CF, Wan SW, Chuang YC, Hsu TK, Liu HS, Liu CC, Anderson R, and Lei HY. 2011. Molecular mimicry between virus and host and its implications for dengue disease pathogenesis. Exp Biol Med ( M a y w o od ). $236: 515-523$. d o i : 10.1258/ebm.2011.010339.

Paranavitane SA, Gomes L, Kamaladasa A, Adikari TN, Wickramasinghe N, Jeewandara C, Shyamali NL, Ogg GS, and Malavige GN. 2014. Dengue NS1 antigen as a marker of severe clinical disease. BMC Infectious Diseases. 14(1):1-7. doi:10.1186/s12879-014-0570-8.

Putnak R, Porter K, and Schmaljohn C. 2003. DNA vaccines for flaviviruses. Advances in Virus Research, 61:445468. doi:10.1016/S0065-3527(03)61012-2.

Ritter T, Brandt C, Prosch S, Vergopoulos A, Vogt K, Kolls J, and Volk HD. 2000. Stimulatory and inhibitory action of cytokines on the regulation of hCMV-IE promoter activity in human endothelial cells. Cytokine. 12: 1163-1170. doi:10.1006/cyto.2000.0689.

Shu PY, Chen LK, Chang SF, Yueh YY, Chow L, Chien LJ, Chin C, Lin TH, and Huang JH, 2000. Dengue NS1specific antibody responses: isotype distribution and serotyping in patients with dengue fever and dengue hemorrhagic fever. Journal of Medical Virology. 62 ( 2 ): $224-232$. doi: 10 . $1002 / 1096$ 9071(200010)62:2<224::AID-JMV14>3.0.CO;2-C.

Simmons CP, Farrar JJ, Nguyen vV, and Wills B. 2012. Dengue. The New England Journal of Medicine. 366(15):1423-1432. doi:10.1056/NEJMra1110265.

Sjatha F, Mustika OC, Budianti A, and Sudiro TM. 2019. Expression of recombinant non structural 1 protein of dengue virus serotype-2 in mammalian cell line. Microbiologi Indonesia. 13(1):36-42. doi:10.5454/mi.13.1.5.

Sjatha F, Mustika OC, Dewi BE, and Sudiro TM. 2019. Production of TNF- $\alpha$ in peripheral blood mononuclear cells induced by recombinant nonstructural 1 protein of dengue virus serotype-2 in vitro. 13(2):64-69. doi:10.5454/mi.13.2.4.

Sun DS, King CC, Huang HS, Shih YL, Lee CC, Tsai WJ, Yu CC, and Chang HH. 2007. Antiplatelet autoantibodies 
elicited by dengue virus non-structural protein 1 cause thrombocytopenia and mortality in mice. Journal of Thrombosis and Haemostasis. 5(11):2291-2299. doi:10.1111/j.1538-7836.2007.02754.x.

Watterson D, Modhiran N, and Young PR. 2016. The many faces of the flavivirus NS1 protein offer a multitude of options for inhibitor design. Antiviral Research. 130:718. doi:10.1016/j.antiviral.2016.02.014.

WHO. 2016. Dengue Control. Retrieved November 12, 2019, from http://www.who.int/denguecontrol/ epidemiology/en/. 